\title{
Genetics research at the "Centenary of human population genetics" conference and SBB-2019
}

\author{
Tatiana V. Tatarinova ${ }^{1,2,3}$, Ludmila E. Tabikhanova ${ }^{4,5}$, Gilda Eslami ${ }^{6,7}$, Haihua Bai ${ }^{8}$ and Yuriy L. Orlov, ${ }^{4,5}, 9^{*}$ \\ From 11th International Young Scientists School "Systems Biology and Bioinformatics" - SBB-2019 \\ Novosibirsk, Russia. 24-28 June 2019
}

Human population genetics has more than hundred year history. Modern next-gen sequencing technologies, genotyping and bioinformatics extended the research boundaries raising new genetics problems. This special issue of BMC Genetics presents the selected works studies discussed at the "Centenary of Human Population Genetics" conference in Moscow in May 2019, organized on the base of Moscow State University (http://www. centenary-popgene.com/). The Conference was focused on the discussion of the research on gene pools of the world's nations, ancient DNA analysis, possibilities of judicial genetics, population-genetic database development, biobanks, and new genomics technologies. It was a unique event referred to as the 100th anniversary of the first human population study in 1919.

This journal special issue contains materials on human genetics and genomics presented at the conference in Moscow and SBB-2019 (Systems Biology and Bioinformatics - 2019) School in Novosibirsk in 2019 (http:// conf.bionet.nsc.ru/sbb2019/en/). The SBB School series on bioinformatics is organized annually since 2008 by the Institute of Cytology and Genetics of the Siberian Branch of the Russian Academy of Sciences and Novosibirsk State University [1]. We have published selected conference materials as special issues at BMC Genetics and related BioMed Central journals [2-5].

The SBB Schools in Novosibirsk are satellite events for BGRSISB (Bioinformatics of Genome Regulation and

\footnotetext{
* Correspondence: orlov@d-health.institute

${ }^{4}$ Institute of Cytology and Genetics SB RAS, 630090 Novosibirsk, Russia

${ }^{5}$ Novosibirsk State University, 630090 Novosibirsk, Russia

Full list of author information is available at the end of the article
}

Structure \Systems Biology) (https://bgrssb.icgbio.ru/2 020) multiconference with genetics sessions $[1,6,7]$. The SBB-2019 School was held as a broad-scope independent meeting, genetics in topics with the human genomics and bioinformatics areas. The special issue on bioinformatics is accompanied by other BMC journal issues in the genomics, bioinformatics, and medical genetics areas at BMC Bioinformatics, BMC Genomics, BMC Medical Genomics, and BMC Medical Genetics, as well as in BMC Microbiology. We continued the BMC Genetics special issues in 2019 [2, 8, 9]. We believe such events and public discussion at the platforms of international publishers will bring the attention of the journal readers to actual genomics challenges.

We open up this Special Issue by the human population genetics study in Africa by the article by Sandra Walsh and colleagues [10] (this issue). African populations are genetically more diverse than any other human population, holding the highest amount of genetic variation, low linkage disequilibrium, and deep population structure. In the process of adaptation of humans to their environment, positive or adaptive selection has played a main role. Positive selection has been understudied in African populations and less presented in such databases as 1000 Genome Project [11]. The authors used about hundred of available whole-genome sequences from five Ethiopian populations to investigate the modes and targets of positive selection. Walsh and colleagues found population-specific and shared signals of selection, with folate metabolism and the related ultraviolet response and skin pigmentation standing out as a shared pathway, possibly as a response to the high 
levels of ultraviolet irradiation, and in addition strong signals in genes such as IFNA, MRC1, immunoglobulins and $\mathrm{T}$-cell receptors which contribute to defend against pathogens.

Maxat Zhabagin et al. [12] (this issue) present population genetics study in continental Asia. The authors analyzed the medieval Mongolian roots of paternal lineages from Kazakhstan. The majority of the Kazakhs from South Kazakhstan belong to the twelve clans of the Senior Zhuz. According to traditional genealogy, nine of these clans have a common ancestor and constitute the Uissun tribe [13]. The authors have genotyped 490 samples of South Kazakhs by set of Y-chromosomal SNPs. The Y-chromosomal variation in Kazakh clans indicates their common origin in medieval times, in agreement with the traditional genealogy [14]. Zhabagin and coauthors show that the Y-chromosomal lineages of South Kazakhstan were brought by the migration of the population related to the medieval Niru'un Mongols.

Work by Vladimir Babenko and colleagues [15] (this issue) analyze continental populations for variability in optical disk size morphology. GFI1 (Growth Factor Independent Transcription Repressor 1) is a development gene which is likely to affect optic disk area by altering the expression of the associated genes via long-range interactions. Role of gene regulatory regions in the human genome were discussed in [16] as part of special postconference Supplement issues at BioMed Central Distribution of haplotypes in the putative enhancer region has been assessed using the data on four continental super groups from the 1000 Genomes Project. The major haplotype appears to be involved in silencing GFI1 repressor gene expression, which might be the cause of increased optic disk area characteristic of the East Asian populations.

Ramjet Das and Priyanka Upadhyai [17] analyzed the Kumhar and Kurcha populations from the India. The authors investigated the genetic origin and population history of the Kumhars, a group of people who inhabit large parts of northern India using the geographic population structure method developed earlier [18]. Das and Upadhyai compared 27 previously published Kumhar SNP genotype data sampled from Uttar Pradesh in north India to various modern day and ancient populations. The analysis show high genomic proximity to the Kurchas, a small and relatively little-known population found far away in Kerala, south India. The findings illuminate the genomic history of two Indian populations, allowing a glimpse into one or few of numerous of human migrations that likely occurred across the Indian subcontinent [19].

Rosa Tiis and co-authors [20] (this issue) studied polymorphic variants of the NAT2 (N-acetyltransferase 2) gene in native populations of Siberia. NAT2 plays a crucial role in the metabolism of a wide range of xenobiotics, including many drugs, carcinogens, and other chemicals in the human environment [21]. This work presents for the first time data on the frequency of two variants of NAT2 gene, which significantly affect the rate of xenobiotics acetylation, among the representatives of indigenous populations of Forest and Tundra Nenets in Northern Siberia. Genetic predispositions to diabetes and related diseases among native Mongolian populations were studied by the authors' group earlier in [22, 23].

The work by Mikhail Ponomarenko and colleagues [24] (this issue) covers fundamental evolution problems of natural selection by male reproductive potential. The concept of reproductive potential denotes the most vital indicator of chances to produce and sustain a healthy descendant. The authors continued study on singlenucleotide polymorphisms (SNP) in TATA-binding protein binding sites in human gene promoters $[25,26]$. The authors found in silico new candidate SNP markers of male reproductive potential.

The other works consider genetics application in model organisms. These articles discuss genetics application in Drosophila, highlighted, in turn, at SBB'2019 School in Novosibirsk.

Anna Ogienko et al. [27] (this issue) analyzed Drosophila lines for Gal4 gene. The authors provide a miniatlas of the spatial activity of Gal4 drivers that are widely used for the expression of UAS genes in the Drosophila [28, 29].

Mikhail Shaposhnikov and co-authors [30] (this issue) consider problems of aging and affecting life span on fruit flies. Beta-amyloid peptide $(A \beta)$ is the key protein in the pathogenesis of Alzheimer's disease, the most common age-related neurodegenerative disorder in humans. The authors used the Drosophila model [31] to study mechanisms underlying a dual role for $A \beta$ peptides.

The work by Natalia Blazhko et al. [32] concludes this issue by analysis of virulence properties for bovine leukemia virus. This study describes the biodiversity and properties of this virus in Western Siberia. The paper explores the effect of different genotypes of the env gene of the cattle leukemia virus on hematological parameters of infected animals. The authors note that monitoring the origin of new virus mutations is of great importance for veterinary and animal husbandry, as every new strain may have unique features of interaction with the host organism. The problems of hazards control in food safety related to infectious diseases became important due to the SARS-CoV-2 pandemic [33]. Genetics studies on model organisms have new value in relation to the infectious disease resistance, adaptations of human populations to environment, and natural polymorphism. 
We aim to support international exchanges and education in the form of international conferences and schools for young scientists on bioinformatics, genetics and systems biology [1] (https://peerj.com/collections/72-bgrssb-2020/). We invite our readers worldwide to attend the systems biology meetings in Russia - Digital Medicine Forum and MGNGS-2020 (Medical Genetics Next-Generation Sequencing) event postponed to 2021 (http://ngs.med-gen.ru/mgngs20/).

\section{Acknowledgments}

We are grateful to Prof. O.P. Balanovsky for the organization of the "Centenary of Human Population Genetics" Conference in Moscow in 2019 and compiling materials for the SBB-2019 issues at BioMed Central journals. We thank Academician N.A. Kolchanov, Prof. A.V. Baranova, and the Program Committee of SBB School and BGRS conferences series for organizations of the meetings in Novosibirsk and constant support of the authors.

LT and YO were funded by the Russian Science Foundation (grant 19-1500219).

The guest editors of the special issue are grateful to the conference and school committee members and all the reviewers who helped in the peerreview and the special issue preparation. We thank Hildegard Nikki Hall (University of Edinburgh, UK), Piramanayagam Shanmughavel (Bharatiar University, India), Haiqing Zhao (Columbia University Medical Center, USA), Vitaly Gursky (St.Petersburg Polytech University, Russia), Igor Rogozin (NIH, USA), Elvira Galieva (Novosibirsk State University, Russia), Alexey Kolodkin (University of Luxemburg, Luxemburg), Alexander Ratushny (Bristol Myers Squibb, USA), Olga Arkova (Institute of Gene Biology RAS, Moscow), Eric Mjolsness (Irvine University, USA), Daria Skuratovskaya (I.Kant Baltic Federal University, Kaliningrad), Paul Jones (AIC Inc., USA), Shuan Li (University of Rhode Island, USA), Mengting Liu (University of Southern California, USA), Lydia Manor (AIC Inc., USA), Guohao Wang (NIH, USA), Nina Oparina (Karolinska Institut, Sweden), Stanislav Rybtsov (University of Edinburgh, UK), Ed Hollox (University of Leicester, USA), Igor Sharakhov (Virginia Tech, USA), Ludmila Zakharenko (Institute of Cytology and Genetics SB RAS, Novosibirsk, Russia), Alexander Konev (NRC "Kurchatov Institute" - PNPI, Gatchina, Russia), Angelica Timofeeva (Moscow State University, Russia), Anatoly Ivashchenko (al-Farabi Kazakh National University, Kazakhstan), Ekaterina Marakasova (US FDA, USA), Chris Tyler (Sanger Centre, UK), Dmitry Karpov (Institute of Biomedical Chemistry RAS), Nikolai Barlev (Institute of Cytology RAS, St.-Petersburg, Russia), Lyubov Chuvakova (Moscow State University, Russia), Andrei Krivtsov (Dana Farber Cancer Institute, USA), Olga Tarasova (Sechenov University, Moscow, Russia), Nadezhda Antipova (Moscow State University, Russia), Oleg Gusev (RIKEN, Japan), Hua Zhong (Fred Hutchinson Cancer Research Center, USA), Elena Zaklyazminskaya (Petrovsky Russian Research Centre of Surgery, Russia), Michael Linderman (Icahn School of Medicine at Mount Sinai, USA), Igor Berezovsky (Bioinformatics Institute, Singapore), Andreas Laner (Medizinisch Genetisches Zentrum, Munich, Germany), Arun Kumar (Shanmugha Arts Science Technology and Research Academy, India), Lars Fehren-Schmitz (University of California Santa Cruz, USA), Mikhail Sadovsky (Siberian Federal University, Krasnoyarsk, Russia), Elena Leberfarb, Svetlana Fedorova and Nataliya Dorogova (Institute of Cytology and Genetics SB RAS, Novosibirsk, Russia), Vasily Ramensky (National Research Institute of Preventive Medicine, Moscow, Russia), Patrick Harrison (University College Cork, Ireland).

\section{About this supplement}

This article has been published as part of BMC Genetics Volume 21 Supplement 1, 2020: Selected Topics in "Systems Biology and Bioinformatics" 2019: genetics. The full contents of the supplement are available online at https://bmcgenet.biomedcentral.com/articles/supplements/volume-21supplement-1.

\section{Authors' contributions}

$\Pi$, and $\mathrm{YO}$ are guest editors of the special post-conference issues and Program Committee members of SBB-2019 School. LT, GE, HB are the invited editors and the committee members of the conferences. All the authors read, revised, and approved the final manuscript.

\section{Funding}

Publication of this article was not covered by sponsorship.

\section{Competing interests}

The authors declare that they have no competing interests.

\section{Author details}

${ }^{1}$ Department of Biology, University of La Verne, La Verne, CA 91750, USA. ${ }^{2}$ Department of Fundamental Biology and Biotechnology, Siberian Federal University, 660074 Krasnoyarsk, Russia. ${ }^{3}$ N.I.Vavilov Institute of General Genetics RAS, 119991 Moscow, Russia. Institute of Cytology and Genetics SB RAS, 630090 Novosibirsk, Russia. ${ }^{5}$ Novosibirsk State University, 630090 Novosibirsk, Russia. ${ }^{6}$ Research Center for Food Hygiene and Safety, School of Public Health, Shahid Sadoughi University of Medical Sciences, Yazd 8916188638, Iran. ${ }^{7}$ Department of Parasitology and Mycology, School of Medicine, Shahid Sadoughi University of Medical Sciences, Yazd 8916188638, Iran. ${ }^{8}$ Inner Mongolia University for the Nationalities, 028000, Tongliao, China. ${ }^{9}$ The Digital Health Institute, I.M.Sechenov First Moscow State Medical University (Sechenov University), 119991 Moscow, Russia.

Published: 22 October 2020

\section{References}

1. Baranova AV, Orlov YL. The papers presented at 7th young scientists school "systems biology and bioinformatics" (SBB'15): introductory note. BMC Genet. 2016:17(Suppl 1):20. https://doi.org/10.1186/s12863-015-0326-5.

2. Orlov YL, Baranova AV, Hofestaedt R, Kolchanov NA. Computational genomics at BGRSISB-2016: introductory note. BMC Genomics. 2016; 17(Suppl 14):996. https://doi.org/10.1186/s12864-016-3350-6.

3. Orlov YL, Kolchanov NA, Hofestädt R, Wong L. Editorial - bioinformatics development at the BGRSISB conference series: 10th anniversary. J Bioinforma Comput Biol. 2017;15(2):1702001. https://doi.org/10.1142/ S0219720017020012

4. Tatarinova TV, Chen M, Orlov YL. Bioinformatics research at BGRS-2018. BMC Bioinformatics. 2019;20(Suppl 1):33. https://doi.org/10.1186/s12859-0182566-7.

5. Orlov YL, Baranova AV. Editorial: Bioinformatics of genome regulation and systems biology. Front Genet. 2020;11:625. https://doi.org/10.1186/s12864016-3350-6.

6. Orlov YL, Baranova AV, Markel AL. Computational models in genetics at BGRSISB-2016: introductory note. BMC Genet. 2016;17(Suppl 3):155. https:// doi.org/10.1186/s12863-016-0465-3.

7. Orlov YL, Baranova AV, Tatarinova TV, Kolchanov NA. Genetics at Belyaev Conference - 2017: introductory note. BMC Genet. 2017;18(Suppl 1):116. https://doi.org/10.1186/s12863-017-0577-4.

8. Orlov YL, Kochetov AV, Li G, Kolchanov NA. Genomics research at bioinformatics of genome regulation and structure systems biology (BGRSISB) conferences in Novosibirsk. BMC Genomics. 2019;20(Suppl 3):322. https://doi.org/10.1186/s12864-019-5534-3.

9. Orlov YL, Galieva ER, Melerzanov AV. Computer genomics research at the bioinformatics conference series in Novosibirsk. BMC Genomics. 2019; 20(Suppl 7):537. https://doi.org/10.1186/s12864-019-5846-3.

10. Walsh S, Pagani L, Xue Y, Laayouni H, Tyler-Smith C, Bertranpetit J. Positive selection in admixed populations from Ethiopia. BMC Genet. 2020;21(Suppl 1):S2. https://doi.org/10.1186/s12863-020-00908-5.

11. Gurdasani D, Carstensen T, Tekola-Ayele F, Pagani L, Tachmazidou I, Hatzikotoulas K, et al. The African genome variation project shapes medical genetics in Africa. Nature. 2015;517(7534):327-32. https://doi.org/10.1038/ nature13997.

12. Zhabagin M, Sabitov Z, Tarlykov P, Tazhigulova I, Junissova Z, Yerezhepov D, Akilzhanov R, Zholdybayeva E, Wei L, Akilzhanova A, Balanovsky O, Balanovska $E$. The medieval Mongolian roots of paternal lineages from South Kazakhstan. BMC Genet. 2020;21(Suppl 1):S3. https://doi.org/10.1186/ s12863-020-00897-5.

13. Ashirbekov YY, Khrunin AV, Botbayev DM, Belkozhaev AM, Abaildayev AO, Rakhimgozhin MB, Mukushkina DD, Limborska SA, Aitkhozhina N. Molecular genetic analysis of population structure of the great Zhuz Kazakh tribal union based on Y-chromosome polymorphism. Mol Genet Microbiol Virol. 2018;33(2):91-6. https://doi.org/10.3103/S0891416818020040.

14. Wei LH, Yan S, Lu Y, Wen SQ, Huang YZ, Wang LX, et al. Whole-sequence analysis indicates that the $\mathrm{Y}$ chromosome $\mathrm{C} 2^{*}$-star cluster traces back to 
ordinary Mongols, rather than Genghis khan. Eur J Hum Genet. 26(2):230-7. https://doi.org/10.1038/s41431-017-0012-3.

15. Babenko VN, Babenko RO, Orlov YL. Analyzing a putative enhancer of optic disk morphology. BMC Genet. 2020;21(Suppl 1):S4. https://doi.org/10.1186/ s12863-020-00873-z.

16. Babenko V, Chadaeva I, Orlov Y. Genomic landscape of CpG rich elements in human genome. BMC Evol Biol. 2017;17(Suppl 1):19.https://doi.org/10. 1186/s12862-016-0864-0.

17. Das R, Upadhyai P. The story of the lost twins: decoding the genetic identities of the Kumhar and Kurcha populations from the Indian subcontinent. BMC Genet. 2020;21(Suppl 1):S5. https://doi.org/10.1186/ s12863-020-00919-2.

18. Das R, Upadhyai P. Application of geographic population structure (GPS) algorithm for biogeographical analyses of populations with complex ancestries: a case study of south Asians from 1000 genomes project. BMC Genet. 2017;18(Suppl 1):109. https://doi.org/10.1186/s12863-017-0579-2.

19. Triska P, Chekanov N, Stepanov V, Khusnutdinova EK, Kumar GPA, Akhmetova V, Babalyan K, Boulygina E, Kharkov V, Gubina M, et al. Between Lake Baikal and the Baltic Sea: genomic history of the gateway to Europe. BMC Genet. 2017; 18(Suppl 1):110. https:/doi.org/10.1186/s12863-017-0578-3.

20. Tiis RP, Osipova LP, Lichman DV, Voronina EN, Filipenko ML. Studying polymorphic variants of the NAT2 gene (NAT2*5 and NAT2*7) in Nenets populations of northern Siberia. BMC Genet. 2020;21(Suppl 1):S6.

21. Magalon H, Patin E, Austerlitz F, Hegay T, Aldashev A, Quintana-Murci L, Heyer E. Population genetic diversity of the NAT2 gene supports a role of acetylation in human adaptation to farming in Central Asia. Eur J Hum Genet. 2008;16(2):243-51. https://doi.org/10.1038/sj.ejhg.5201963.

22. Bai H, Liu H, Suyalatu S, Guo X, Chu S, Chen Y, Lan T, Borjigin B, Orlov YL, Posukh OL, Yang X, Guilan G, Osipova LP, Wu Q, Narisu N. Association analysis of genetic variants with type 2 diabetes in a Mongolian population in China. J Diabetes Res. 2015;2015:613236. https://doi.org/10.1155/2015/613236.

23. Wu Q, Wu H, Orlov YL, Gegentana G, Huo W, Bragin AO, Wu N, Suyalatu S, Zhao F, Zhao J, Tabikhanova LE, Chen M, Bai H. Genetic polymorphisms and related risk factors of ischemic stroke in a Mongolian population in China. Vavilovskii Zhurnal Genetiki Selektsii. 2017;21(5):581-7. (In Russian). https:// doi.org/10.18699/NJ17.275.

24. Ponomarenko M, Kleshchev M, Ponomarenko P, Chadaeva I, Sharypova E, Rasskazov D, Kolmykov S, Drachkova I, Obanina N, Vasiliev G, Gutorova N, Ignatieva E, Savinkova L, Bogomolov A, Osadchuk L, Osadchuk A, Oshchepkov D. Disruptive natural selection by male reproductive potential prevents underexpression of protein-coding genes on the human $Y$ chromosome as a self-domestication syndrome. BMC Genet. 2020;21(Suppl 1):S7. https://doi.org/10.1186/s12863-020-00896-6.

25. Chadaeva IV, Ponomarenko PM, Rasskazov DA, Sharypova EB, Kashina EV, Zhechev DA, Drachkova IA, Arkova OV, Savinkova LK, Ponomarenko MP, Kolchanov NA, Osadchuk LV, Osadchuk AV. Candidate SNP markers of reproductive potential are predicted by a significant change in the affinity of TATA-binding protein for human gene promoters. BMC Genomics. 2018; 19(Suppl 3):0. https://doi.org/10.1186/s12864-018-4478-3.

26. Chadaeva IV, Ponomarenko MP, Rasskazov DA, Sharypova EB, Kashina EV, Matveeva MY, Arshinova TV, Ponomarenko PM, Arkova OV, Bondar NP, Savinkova LK, Kolchanov NA. Candidate SNP markers of aggressivenessrelated complications and comorbidities of genetic diseases are predicted by a significant change in the affinity of TATA-binding protein for human gene promoters. BMC Genomics. 2016;17(Suppl 14):995. https://doi.org/10. 1186/s12864-016-3353-3.

27. Ogienko AA, Andreyeva EN, Omelina ES, Oshchepkova AL, Pindyurin AV. Molecular and cytological analysis of widely-used Gal4 driver lines for Drosophila neurobiology. BMC Genet. 2020;21(Suppl 1):S8. https://doi.org/10. 1186/s12863-020-00895-7.

28. Ogienko AA, Yarinich LA, Fedorova EV, Lebedev MO, Andreyeva EN, Pindyurin AV, Baricheva EM. New slbo-Gal4 driver lines for the analysis of border cell migration during Drosophila oogenesis. Chromosoma. 2018; 127(4):475-87. https://doi.org/10.1007/s00412-018-0676-7.

29. Andreyeva EN, Ogienko AA, Dubatolova TD, Oshchepkova AL, Kozhevnikova EN, Ivankin AV, Pavlova GA, Kopyl SA, Pindyurin AV. A toolset to study functions of cytosolic non-specific dipeptidase 2 (CNDP2) using Drosophila as a model organism. BMC Genet. 2019;20(Suppl 1):31. https://doi.org/10. 1186/s12863-019-0726-z.

30. Shaposhnikov MV, Zemskaya NV, Koval LA, Minnikhanova NR, Kechko Ol, Mitkevich VA, Makarov AA. Moskalev AA Amyloid- $\beta$ peptides slightly affect lifespan or antimicrobial peptide gene expression in Drosophila melanogaster. BMC Genet. 2020;21(Suppl 1):S9.

31. Moskalev A, Shaposhnikov M, Proshkina E, Belyi A, Fedintsev A, Zhikrivetskaya S, Guvatova Z, Sadritdinova A, Snezhkina A, Krasnov G, et al. The influence of pro-longevity gene Gclc overexpression on the agedependent changes in Drosophila transcriptome and biological functions. BMC Genomics. 2016;17(Suppl 14):273-89:1046. https://doi.org/10.1186/ s12864-016-3356-0.

32. Blazhko N, Vyshegurov S, Donchenko A, Shatokhin K, Ryabinina V, Plotnikov K, Khodakova A, Paskovskiy S. Genotypes diversity of env gene of Bovine leukemia virus in Western Siberia. BMC Genet. 2020;21(Suppl 1):S10. https:// doi.org/10.1186/s12863-020-00874-y.

33. Ahmadiara E. Possibility of Faecal-Oral Transmission of Novel Coronavirus (SARS-CoV-2) via Consumption of Contaminated Foods of Animal Origin: A Hypothesis. J Food Qual Hazards Control. 2020;7(1):2-3. https://doi.org/10. 18502/jfghc.7.1.2445

\section{Publisher's Note}

Springer Nature remains neutral with regard to jurisdictional claims in published maps and institutional affiliations.
Ready to submit your research? Choose BMC and benefit from:

- fast, convenient online submission

- thorough peer review by experienced researchers in your field

- rapid publication on acceptance

- support for research data, including large and complex data types

- gold Open Access which fosters wider collaboration and increased citations

- maximum visibility for your research: over $100 \mathrm{M}$ website views per year

At $\mathrm{BMC}$, research is always in progress.

Learn more biomedcentral.com/submissions 